\title{
PENGGUNAAN FITUR HOG BERBASIS SUPERPIXEL UNTUK KLASIFIKASI JENIS JAMUR DENGAN METODE SVM
}

\author{
Yohannes $^{1^{*}}$, Nur Rachmat ${ }^{2}$ dan Calvin Oliver Saputra ${ }^{3}$ \\ Program Studi Teknik Informatika, Universitas Multi Data Palembang, Palembang ${ }^{1,2,3}$ \\ e-mail: yohannesmasterous@mdp.ac.id ${ }^{1}$,nur.rachmat@mdp.ac.id ${ }^{2}$, calvin.os663@gmail.com ${ }^{3}$
}

\begin{abstract}
Abstrak
Jamur memiliki banyak ragam dengan ciri yang mirip sehingga terdapat masalah dalam pengklasifikasian jenis dari jamur. Dataset citra jamur yang digunakan bernama Mushrooms classification - Common genus's images yang berisi sembilan jenis jamur, yaitu Agaricus, Amanita, Boletus, Cortinarius, Entoloma, Hygrocybe, Lactarius, Russula, dan Suillus. Penggunaan fitur segmentasi dapat meningkatkan akurasi untuk masalah pengklasifikasian. Salah satu fitur segmentasi yang dapat digunakan adalah Superpixel (SLIC). Penelitian ini menggunakan dataset citra jamur yang di-resize. Metode SLIC digunakan untuk mensegmentasi citra jamur ke bentuk superpixel. Segmentasi citra ke superpixel ditujukan untuk mengkelompokkan piksel yang sejenis ke dalam region sehingga citra mudah diolah. HOG adalah fitur ekstraksi untuk mendeteksi objek. SVM sering digunakan sebagai metode klasifikasi karena mampu menghasilkan akurasi yang baik sehingga dapat mempelajari dan mengenali citra jamur. Penggunaan superpixel sebagai fitur segmentasi dengan jumlah region 1.200, kernel radial basis function (RBF), C bernilai sepuluh dan gamma scale memberikan hasil terbaik dengan akurasi sebesar 0,8329. Berdasarkan hasil pengujian yang didapat pada penelitian ini, superpixel dapat meningkatkan akurasi dari SVM pada dataset jamur dibandingkan dengan tanpa superpixel.
\end{abstract}

Kata kunci: Jamur; HOG; Superpixel; SVM; SLIC

\begin{abstract}
Similar characteristics of Mushrooms made problems in classifying the types of mushrooms. The mushroom image dataset used with name Mushrooms classification - Common genus images which contains nine types of mushroom, namely Agaricus, Amanita, Boletus, Cortinarius, Entoloma, Hygrocybe, Lactarius, Russula, and Suillus. The use of segmentation features can improve accuracy for classification problems. One of the segmentation features is Superpixel (SLIC). This study uses a resized mushroom image dataset. SLIC method is used to segment the mushroom image into superpixel form. Image segmentation to superpixel is intended to group similar pixels into regions so that the image is easy to process. HOG is an extraction feature for object detection. SVM is often used as a classification method because it can produce good accuracy so that it can study and recognize mushroom images. The use of superpixel as a segmentation feature with a total of 1,200 regions, a kernel radial basis function (RBF), $C$ is worth ten and a gamma scale gives the best results with an accuracy of 0.8329. Based on the test results obtained in this study, superpixel can improve the accuracy of SVM on the mushroom dataset compared to without superpixel.
\end{abstract}

Keywords: Mushroom; HOG; Superpixel; SVM; SLIC 


\section{PENDAHULUAN}

Jamur adalah salah satu tanaman yang sangat beragam jenisnya [1]. Ciri-ciri tiap jenis jamur memiliki kesamaan jika dilihat kasatmata . Hal ini menjadi kesulitan dalam mengklasifikasikan jenis jamur. Penelitian terkait klasifikasi jamur telah dilakukan dengan metode ANN dan ANFIS dengan hasil akurasi ANFIS lebih baik dari ANN sebesar 70\% [2] dan klasifikasi jenis jamur menggunakan metode SVM dengan fitur HSV dan HOG [3] yang mendapatkan hasil kurang baik karena fitur yang digunakan tidak cukup untuk mengetahui jenis jamur yang diuji. Sehingga dapat disimpulkan bahwa masih terdapat kesulitan dalam pengklasifikasian jenis jamur.

Superpixel merupakan algoritma yang sangat berguna dalam computer vision dan pemrosesan citra. Superpixel dapat digunakan dalam proses segmentasi yang akan memberikan informasi yang lebih banyak terkait fitur objek. Penelitian terkait dengan superpixel juga telah digunakan untuk deteksi teks pada natural image [4], hasilnya menunjukan bahwa superpixel berpengaruh besar pada performa deteksi. Metode superpixel juga memiliki kinerja yang lebih baik untuk deteksi objek bergerak [5], dan deteksi perbuatan curang [6].

Histogram of Oriented Gradient (HOG) adalah fitur ekstraksi yang digunakan untuk deteksi objek. Fitur ini akan menghasilkan gradien pada setiap piksel yang akan membentuk seperti objek asli. Fitur HOG telah digunakan pada deteksi kendaraan [7], HOG dapat dijadikan sebagai fitur ekstraksi yang memiliki hasil akurasi yang sangat baik. HOG juga memiliki tingkat akurasi yang baik untuk mengenali warna serta bentuk dengan akurasi lebih besar dari $90 \%$ pada klasifikasi wajah hewan berdasarkan tampak depan [8]. Selain itu, HOG juga dapat digunakan dalam bentuk saliency dengan metode CAS dan mendapatkan hasil yang baik untuk klasifikasi [9], [10].

Support Vector Machine (SVM) adalah algoritma yang biasanya digunakan untuk klasifikasi dan regresi. Metode SVM memiliki tingkat akurasi yang lebih besar dibandingkan dengan metode $k$-Nearest Neighbor (k-NN) [11], [12]. Penelitian terkait yang menggunakan SVM sebagai metode pengklasifikasian seperti untuk pengenalan mobil pada citra digital menggunakan HOG-SVM yang memiliki tingkat akurasi yang baik sebesar 82,5\% [13] dan perbandingan jarak potret dan resolusi kamera [14] dengan metode SVM untuk mengenali angka pada $\mathrm{kWh}$ meter yang mendapatkan hasil yang baik untuk setiap skenario pengujian dengan akurasi tetap lebih besar dari 70\%. Penelitian berkaitan dengan penggunaan HOG berbasis superpixel juga telah digunakan dalam pendeteksian kesalahan dalam phantograph dan kombinasi ini memberikan hasil yang baik [15]. Melihat penggunaan superpixel mampu memberikan hasil yang baik, maka dilakukan klasifikasi jamur menggunakan fitur HOG berbasis superpixel dengan metode SVM.

\section{TINJAUAN PUSTAKA}

\subsection{Jamur}

Jamur adalah tanaman tanpa klorofil yang bersifat parasite. Jamur menyerap makanan melalui dinding sel, dan mengekskresikan enzim ke lingkungan melalui spora dan berkembang biak dengan cara seksual dan aseksual. Jamur memiliki keragaman yang sangat banyak dengan ciriciri tersendiri untuk setiap jenisnya [16].

\section{$2.2 \quad$ Superpixel}

Segmentasi citra melibatkan proses pemisahan citra digital menjadi beberapa kelompok piksel. Salah satu cara untuk mensegmentasi kelompok-kelompok piksel adalah metode superpixel. Superpixel dapat 
didefinisikan sebagai sekelompok piksel yang memiliki karakteristik umum (seperti intensitas piksel, tekstur, warna, tingkat kecerahan, dan lain-lain). Superpixel menjadi berguna dalam algoritma pemrosesan citra seperti pelabelan semantik, deteksi objek dan pelacakan. Hal ini disebabkan karena superpixel membawa lebih banyak informasi daripada piksel dan mampu mengurangi kompleksitas pada proses komputasi yang dilakukan [17].

Metode yang terbaik untuk superpixel adalah Simple Linear Iterative Clustering (SLIC). SLIC bekerja berdasarkan algoritma klasterisasi $k$-means yang bergantung dengan dua parameter, yaitu jumlah superpixel $(K)$ dan compactness. Setiap pixel dideskripsikan oleh vector $v=[L, a, b$, $x, y]$ yang mana terdiri dari ruang warna CIELAB dan lokasi piksel $(x, y)$.

SLIC akan menginisialisasi $|K|$ vector pusat cluster : $C_{1}, C_{2}, \ldots, C_{|K|}$. Untuk superpixel terdekat yang berukuran sama akan ada pusat superpixel pada setiap interval $S=\sqrt{ }(N / K)$, dimana $N$ adalah jumlah dari piksel citra. Karena batas spasial dari setiap superpixel adalah $S^{2}$, maka piksel yang berkaitan dengan pusat cluster terletak dalam daerah $2 S \times 2 S$ di sekitar pusat superpixel pada bidang $x y$ sehingga hal ini menjadi area pencarian untuk piksel terdekat untuk setiap cluster. Dengan menggunakan Euclidean distance, dapat dihitung jarak terhadap ruang warna CIELAB dengan Persamaan (1), jarak terhadap posisi piksel $(x, y)$ sesuai dengan Persamaan (2), dan jarak keseluruhan warna CIELAB dan posisi piksel $(x, y)$ sesuai dengan Persamaan (3).

$d_{l a b}=\sqrt{ }\left(l_{k}-l_{i}\right)^{2}+(a k-a i)^{2}+(b k-b i)^{2}$

$d_{x y}=\sqrt{ }(x k-x i)^{2}+\left(y_{k}-y_{i}\right)^{2}$

$D=\sqrt{ } d_{l a b}{ }^{2}+\left(d_{x y} S\right)^{2} t^{2}$

Sebagai upaya untuk menghindari penempatan superpixel yang keliru, pusat cluster dipindahkan ke lokasi dengan gradien terendah. Gradien citra dapat dihitung dengan Persamaan (4).
$G(x, y)=\|\boldsymbol{I}(x+1, y)-I(x-1, y)\|^{2}+\| \boldsymbol{I}(x, y+$ 1) $-I(x, y-1) \|^{2}$

Nilai $\boldsymbol{I}(x, y)$ adalah vektor Lab yang berkoresponden terhadap posisi piksel $(x, y)$ dan $\|\cdot\|$ adalah normalisasi $L_{2}$. Dengan demikian, untuk setiap piksel ditentukan pada pusat cluster, yang dapat mereduksi jumlah distance.

\subsection{Histogram Of Oriented Gradient}

Histogram of Oriented Gradient (HOG) adalah fitur ekstraksi yang dapat digunakan untuk mendapatkan ciri dari citra. Pertama HOG akan melakukan konversi citra RGB menjadi citra grayscale selanjutnya akan dilakukan proses pembagian cell dan blok, dan setiap blok akan dilakukan perhitungan gradien dari setiap piksel. Cell merupakan kumpulan dari piksel dengan ukuran $8 \times 8$ sedangkan blok merupakan kumpulan dari cell dengan ukurang 2x2. Tahap selanjutnya akan dilakukan proses normalisasi dan perhitungan gradien. Di tahap akhir, dilakukan pemilihan berdasarkan bobot dalam batas spasial dan orientasi cell [8]. Perhitungan gradien dapat ditentukan menggunakan Persamaan (5) dan Persamaan (6).

$I x(r, c)=I(r, c+1)-(r, c-1)$

$I y(r, c)=I(r+1, c)-(r-1, c)$

Setelah proses perhitungan gradien selesai dan didapatkan nilai untuk $I x$ dan $I y$ maka tahap selanjutnya akan dilakukan perhitungan besar gradien $(\mu)$ menggunakan Persamaan (7).

$\mu=\sqrt{I_{x^{2}}+I_{y^{2}}}$

Proses terakhir menghitung arah atau orientasi dari gradien dengan memanfaatkan nilai dari magnitude sehingga didapatkan orientasi berupa vektor yang akan menunjukkan ciri dari citra. Proses akan diulang hingga setiap cell akan mendapatkan orientasi atau vektor. 


\subsection{Support Vector Machine}

SVM adalah salah satu algoritma machine learning yang termasuk dalam metode klasifikasi biner dan dapat digunakan untuk menyelesaikan masalah pengklasifikasian dan regresi. SVM akan membagi titik data dengan memberikan sebuah garis pemisah dengan memanfaatkan persamaan hyperplane dan akan membagi data kedalam kelas-kelas tertentu. Data dipisahkan berdasarkan kelas label seperti yang ditunjukkan Gambar 1.

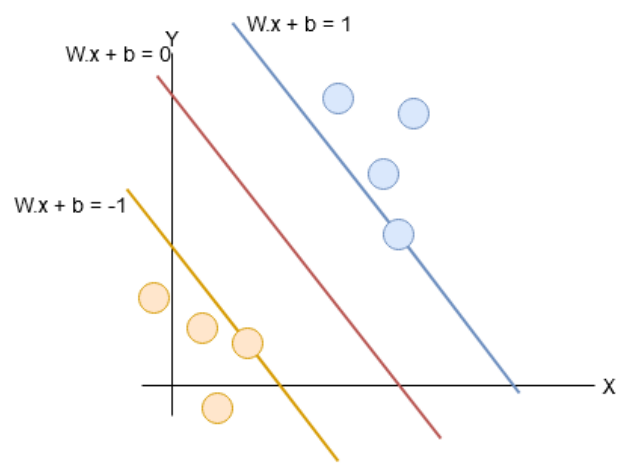

Gambar 1. Pengklasifikasian Metode SVM [18]

\section{METODOLOGI PENELITIAN}

Kerangka kerja penelitian dapat dilihat pada Gambar 2.

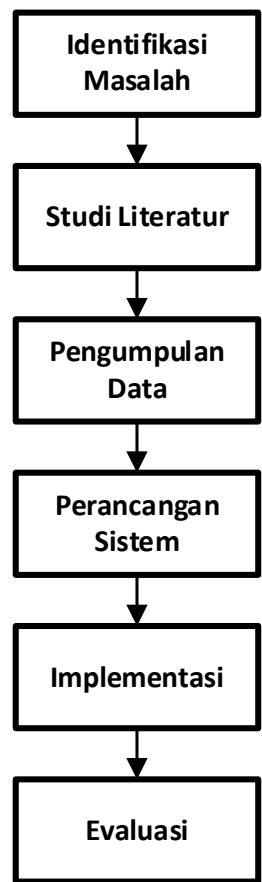

Gambar 2. Kerangka Kerja Penelitian

\subsection{Identifikasi Masalah}

Melakukan identifikasi masalah penelitian berkaitan dengan klasifikasi citra jamur melalui citra dengan memanfaatkan fitur segmentasi dan ekstraksi ciri dengan metode HOG serta klasifikasi menggunakan metode SVM.

\subsection{Studi Literatur}

Tahapan ini merupakan pencarian dan mempelajari beberapa jurnal yang berkaitan dengan klasifikasi jenis jamur dengan berbagai macam metode, jurnal yang berkaitan dengan fitur superpixel, jurnal berkaitan dengan fitur Histogram of Oriented Gradient (HOG), dan buku pendukung yang berkaitan dengan jenisjenis jamur.

\subsection{Pengumpulan Data}

Data yang digunakan dataset public yang berjumlah 2.700 citra jamur. Citra jamur terdiri dari 9 jenis atau genus jamur yaitu Agaricus, Amanita, Boletus, Cortinarius, Entoloma, Hygrocybe, Lactarius, Russula, Suillus. Untuk setiap jenis terdapat 300 citra beresolusi tinggi dengan ukuran asli 800x600 piksel. Dataset yang digunakan adalah Mushrooms classification - Common genus's images [19].

\subsection{Perancangan Sistem}

Tahap ini adalah perancangan sistem yang dibagi kedalam 2 bagian yaitu tahap training dan tahap testing. Tahap training dimulai dari proses resize citra menjadi ukuran 240x320 piksel [3]. Kemudian dilanjutkan ke proses segmentasi dengan superpixel (SLIC) hasil citra dari proses ini akan dimasukkan ke proses ekstraksi ciri menggunakan Histogram of Oriented Gradient (HOG). Pada proses akhir dilakukan pengklasifikasian dengan metode Support Vector Machine (SVM) sehingga dihasilkan model training yang akan 
digunakan pada tahap testing nantinya. Tahap training dapat dilihat pada Gambar 3.

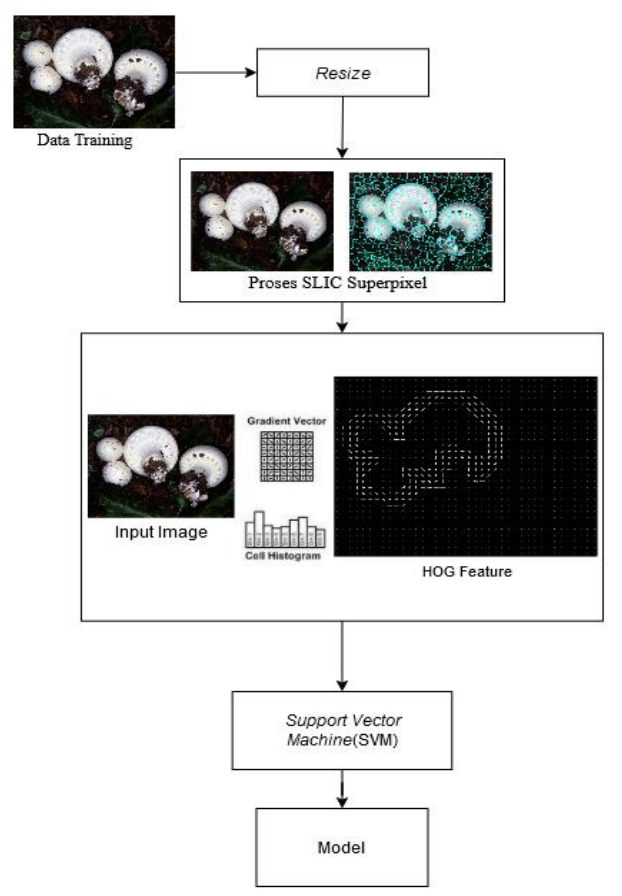

Gambar 3. Tahapan Training

(Sumber : Hasil penelitian, 2021)

Tahapan testing dimulai dari resize citra dan kemudian dilakukan segmentasi dengan superpixel dan ekstraksi dengan HOG. Selanjutnya metode SVM digunakan sebagai classifier dan dibandingkan dengan hasil dari tahap training. Tahapan testing dapat dilihat pada Gambar 4.

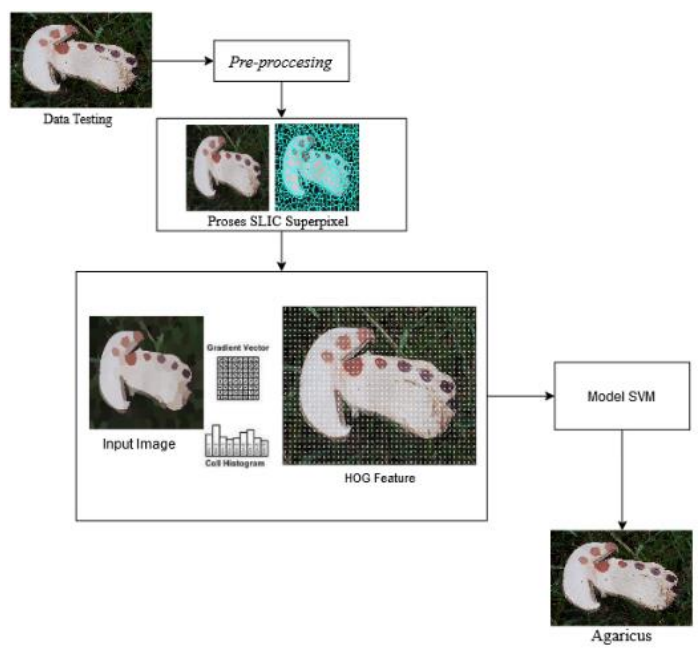

Gambar 4. Tahapan Testing (Sumber : Hasil penelitian, 2021)

\subsection{Implementasi}

Tahap ini menerapkan fitur superpixel dan HOG terhadap citra jamur. Setiap data citra jamur yang telah dibagi menjadi data training dan testing dilakukan ekstraksi fitur HOG berbasis superpixel. Kemudian dilakukan klasifikasi menggunakan metode SVM dengan kernel linear dan RBF.

\subsection{Evaluasi}

Pada tahap ini dilakukan pengujian dari tahap sebelumnya yaitu implementasi. Hasil pengujian berupa nilai akurasi dari perhitungan rata-rata sebanyak 3 kali per jenis jamur. Kemudian hasil klasifikasi dihitung untuk mendapatkan tingkat keberhasilan dari metode yang digunakan yaitu Confussion Matrix yang berupa Accuracy.

\section{HASIL DAN PEMBAHASAN}

\subsection{Hasil HOG Dengan Superpixel}

Penggunaan fitur segmentasi dari superpixel memberikan visualisasi HOG yang berbeda. Fitur segmentasi akan melakukan seleksi terhadap hasil ekstraksi HOG sehingga akan memberikan visualisasi vektor HOG yang lebih menyerupai objek jamur dibandingkan dengan tanpa superpixel. Visualisasi vektor HOG dengan tambahan superpixel dapat dilihat pada Gambar 5. 


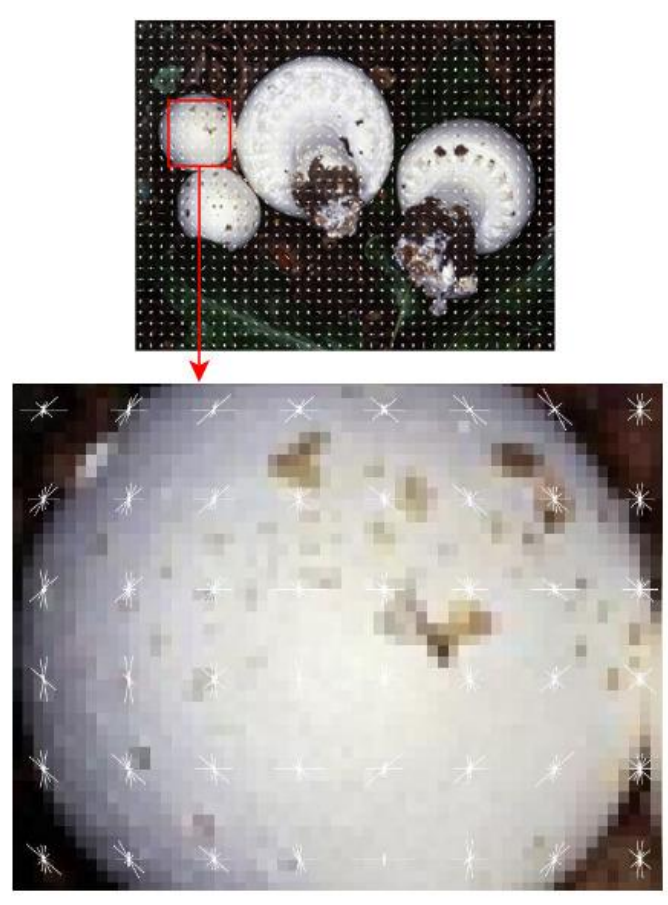

Gambar 5. Gradien Jamur Agaricus HOG-Superpixel

(Sumber : Hasil penelitian, 2021)

\subsection{Hasil Pengujian Fitur HOG Superpixel Terhadap Kernel Linear SVM}

Pengujian dilakukan dengan metode gabungan SVM-HOG berbasis superpixel region 100 hingga 3.000 dengan kelipatan 100 dan SVM-HOG, dimana kernelnya bernilai linear dengan $C$ bernilai 0,$1 ; 1,0$; dan 10 dan gamma bernilai scale. Berdasarkan hasil pengujian didapatkan nilai $\mathrm{C}$ untuk kernel linear tidak mempengaruhi hasil accuracy. Hasil pengujian dengan metode HOG tanpa superpixel mendapatkan akurasi sebesar 0,825 tetapi metode HOG-Superpixel dengan region 1.300 mendapatkan hasil yang lebih baik dengan akurasi sebesar 0,8299 . Perbedaan akurasi sebesar 0,049; hal ini menunjukkan penambahan metode superpixel memberikan peningkatan terhadap akurasi, tetapi variasi nilai $\mathrm{C}$ tidak mempengaruhi hasil dari setiap metode yang digunakan. Hasil pengujian dapat dilihat pada Tabel 1 .
Tabel 1. Hasil Pengujian dengan Kernel Linear (Sumber : Hasil penelitian, 2021)

\begin{tabular}{|l|l|l|l|}
\hline $\begin{array}{l}\text { Metode } \\
\text { HOG }\end{array}$ & $\mathrm{C}=0,1$ & $\mathrm{C}=1,0$ & $\mathrm{C}=10$ \\
\hline SP 100 & 0,8167 & 0,8167 & 0,8167 \\
\hline SP 200 & 0,8148 & 0,8148 & 0,8148 \\
\hline SP 300 & 0,8214 & 0,8214 & 0,8214 \\
\hline SP 400 & 0,8198 & 0,8198 & 0,8198 \\
\hline SP 500 & 0,8255 & 0,8255 & 0,8255 \\
\hline SP 600 & 0,8272 & 0,8272 & 0,8272 \\
\hline SP 700 & 0,8203 & 0,8203 & 0,8203 \\
\hline SP 800 & 0,8198 & 0,8198 & 0,8198 \\
\hline SP 900 & 0,8296 & 0,8296 & 0,8296 \\
\hline SP 1000 & 0,8250 & 0,8250 & 0,8250 \\
\hline SP 1100 & 0,8296 & 0,8296 & 0,8296 \\
\hline SP 1200 & 0,8263 & 0,8263 & 0,8263 \\
\hline SP 1300 & 0,8299 & 0,8299 & 0,8299 \\
\hline SP 1400 & 0,8244 & 0,8244 & 0,8244 \\
\hline SP 1500 & 0,8261 & 0,8261 & 0,8261 \\
\hline SP 1600 & 0,8269 & 0,8269 & 0,8269 \\
\hline SP 1700 & 0,8255 & 0,8255 & 0,8255 \\
\hline SP 1800 & 0,8280 & 0,8280 & 0,8280 \\
\hline SP 1900 & 0,8263 & 0,8263 & 0,8263 \\
\hline SP 2000 & 0,8244 & 0,8244 & 0,8244 \\
\hline SP 2100 & 0,8272 & 0,8272 & 0,8272 \\
\hline SP 2200 & 0,8255 & 0,8255 & 0,8255 \\
\hline SP 2300 & 0,8250 & 0,8250 & 0,8250 \\
\hline SP 2400 & 0,8261 & 0,8261 & 0,8261 \\
\hline SP 2500 & 0,8272 & 0,8272 & 0,8272 \\
\hline SP 2600 & 0,8244 & 0,8244 & 0,8244 \\
\hline SP 2700 & 0,8230 & 0,8230 & 0,8230 \\
\hline SP 2800 & 0,8255 & 0,8255 & 0,8255 \\
\hline SP 2900 & 0,8239 & 0,8239 & 0,8239 \\
\hline SP 3000 & 0,8263 & 0,8263 & 0,8263 \\
\hline Non SP & 0,8250 & 0,8250 & 0,8250 \\
\hline
\end{tabular}




\subsection{Hasil Pengujian Fitur HOG} Superpixel Terhadap Kernel RBF SVM

Pengujian menggunakan metode gabungan SVM-HOG berbasis superpixel region 100 hingga 3.000 dengan kelipatan 100 dan SVM-HOG tanpa superpixel, kernel yang digunakan RBF dengan $C$ bernilai 0,1 ; 1,0; dan 10 dan gamma bernilai scale. Berdasarkan hasil pengujian didapatkan accuracy terbaik dengan menggunakan metode HOG-SP dengan region 1.200 dan nilai $C$ sebesar 10 dengan accuracy sebesar 0,8329. Untuk HOG tanpa superpixel terbaik pada $\mathrm{C}$ sebesar 1 dengan akurasi sebesar 0,8326 . Berdasarkan percobaan kernel RBF hasil terbaik didapatkan oleh HOGSuperpixel dengan region 1.200 dengan C sebesar 10 dan gamma scale. Dengan kernel $\mathrm{RBF}$ nilai C 0,1 selalu menjadi yang terburuk dari 2 lainnya. Hasil pengujian dapat dilihat pada Tabel 2.

Tabel 2. Hasil Pengujian dengan Kernel RBF (Sumber : Hasil penelitian, 2021)

\begin{tabular}{|l|l|l|l|}
\hline $\begin{array}{l}\text { Metode } \\
\text { HOG }\end{array}$ & $\mathrm{C}=0,1$ & $\mathrm{C}=1,0$ & $\mathrm{C}=10$ \\
\hline SP 100 & 0,8165 & 0,8167 & 0,8148 \\
\hline SP 200 & 0,8162 & 0,8154 & 0,8204 \\
\hline SP 300 & 0,8255 & 0,8250 & 0,8192 \\
\hline SP 400 & 0,8230 & 0,8165 & 0,8239 \\
\hline SP 500 & 0,8302 & 0,8302 & 0,8294 \\
\hline SP 600 & 0,8241 & 0,8288 & 0,8294 \\
\hline SP 700 & 0,8206 & 0,8283 & 0,8247 \\
\hline SP 800 & 0,8222 & 0,8307 & 0,8299 \\
\hline SP 900 & 0,8241 & 0,8252 & 0,8274 \\
\hline SP 1000 & 0,8269 & 0,8298 & 0,8263 \\
\hline SP 1100 & 0,8228 & 0,8310 & 0,8324 \\
\hline SP 1200 & 0,8239 & 0,8310 & 0,8329 \\
\hline SP 1300 & 0,8299 & 0,8299 & 0,8313 \\
\hline SP 1400 & 0,8209 & 0,8280 & 0,8294 \\
\hline SP 1500 & 0,8240 & 0,8299 & 0,8299 \\
\hline
\end{tabular}

\begin{tabular}{|l|l|l|l|}
\hline SP 1600 & 0,8214 & 0,8280 & 0,8277 \\
\hline SP 1700 & 0,8217 & 0,8285 & 0,8280 \\
\hline SP 1800 & 0,8200 & 0,8269 & 0,8277 \\
\hline SP 1900 & 0,8192 & 0,8305 & 0,8316 \\
\hline SP 2000 & 0,8200 & 0,8285 & 0,8199 \\
\hline SP 2100 & 0,8209 & 0,8277 & 0,8316 \\
\hline SP 2200 & 0,8209 & 0,8263 & 0,8285 \\
\hline SP 2300 & 0,8217 & 0,8296 & 0,8302 \\
\hline SP 2400 & 0,8214 & 0,8294 & 0,8277 \\
\hline SP 2500 & 0,8211 & 0,8307 & 0,8316 \\
\hline SP 2600 & 0,8206 & 0,8296 & 0,8288 \\
\hline SP 2700 & 0,8214 & 0,8288 & 0,8261 \\
\hline SP 2800 & 0,8203 & 0,8274 & 0,8263 \\
\hline SP 2900 & 0,8209 & 0,8280 & 0,8277 \\
\hline SP 3000 & 0,8192 & 0,8280 & 0,8263 \\
\hline Non SP & 0,8233 & 0,8326 & 0,8310 \\
\hline
\end{tabular}

\subsection{Perbandingan Kernel Linear dan Kernel RBF}

Pada bagian ini dilakukan perbandingan metode terbaik dari kernel linear dengan metode terbaik dari kernel RBF. Perbandingan dilakukan terhadap accuracy yang ditunjukkan pada Gambar 6 .

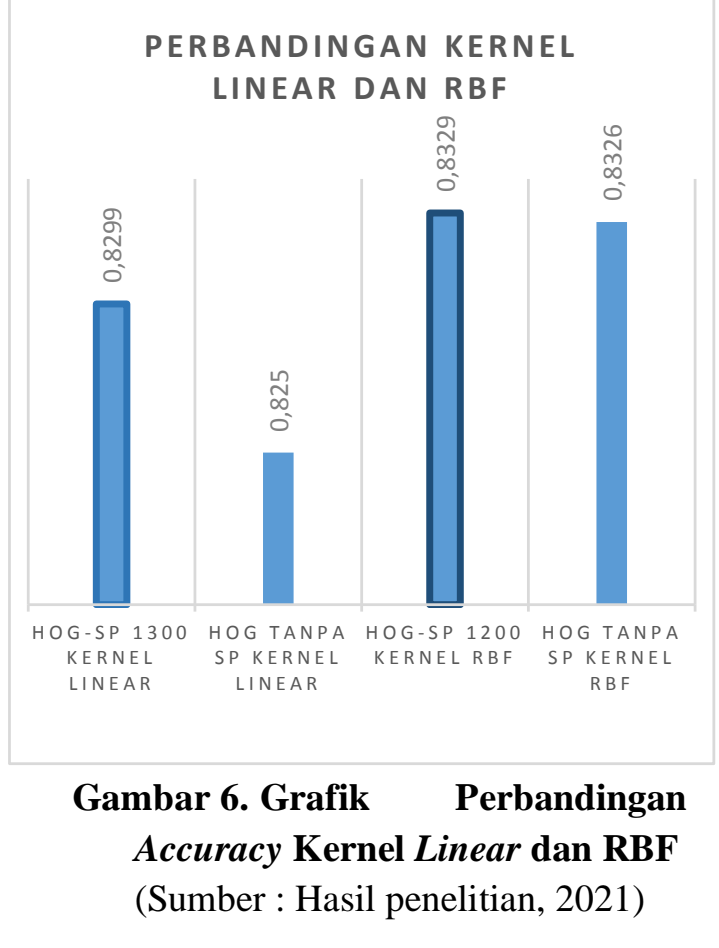


Berdasarkan Gambar 6, kernel linear didapatkan jumlah region terbaik pada 1.300 dan metode ini dapat mengungguli metode HOG tanpa superpixel dengan kernel yang sama, yaitu linear. Metode HOG-Superpixel 1.300 lebih unggul dengan accuracy sebesar 0,8299 .

Untuk kernel RBF metode HOGSuperpixel terbaik didapatkan pada region 1.200 dengan nilai $\mathrm{C}$ sebesar 10 dan gamma scale dan untuk metode HOG tanpa superpixel dengan kernel RBF dan gamma scale terbaik ada pada nilai $\mathrm{C}$ sebesar 1,0 . Metode HOG-Superpixel region 1.200 kernel RBF lebih unggul dari metode HOG tanpa superpixel dengan kernel yang sama.

Metode terbaik untuk kernel linear ada pada HOG-Superpixel region 1.300 dan untuk kernel RBF metode terbaik ada pada HOG-Superpixel region 1.200 dengan nilai $\mathrm{C}$ sebesar 10 dan gamma scale. Jika kedua metode tersebut dibandingkan maka metode terbaik ada pada kernel RBF HOGSuperpixel region 1.200 dengan nilai $\mathrm{C}$ sebesar 10 dan gamma scale.

\section{KESIMPULAN}

Berdasarkan hasil yang didapat dalam penelitian ini, dapat ditarik beberapa kesimpulan yaitu, nilai $\mathrm{C}$ untuk kernel linear tidak mempengaruhi hasil dari klasifikasi jamur, pengklasifikasian jamur terbaik didapat dengan metode HOG berbasis Superpixel dengan region 1.200, kernel Radial Basis Function (RBF), nilai C sebesar 10 dan gamma scale dengan akurasi sebesar 0,8329, jenis jamur yang terbaik diklasifikasikan adalah Boletus dan terburuk pada Entoloma dan Russula, dan dapat disimpulkan penggunaan fitur segmentasi Superpixel dapat mempengaruhi hasil ekstraksi dari metode HOG sehingga hasil dari klasifikasi lebih baik dibandingan tanpa Superpixel.

\section{SARAN}

Pada penelitian selanjutnya dapat dilakukan dengan mengganti fitur segmentasi selain Superpixel, mengganti fitur ekstraksi selain HOG, menggunakan metode klasifikasi SVM menjadi jaringan saraf tiruan, dan melakukan seleksi terhadap dataset jamur yang dianggap buruk.

\section{DAFTAR PUSTAKA}

[1] M. Kuo, 100 Edible Mushrooms. 2007.

[2] S. K. Verma and M. Dutta, "Mushroom Classification Using ANN and ANFIS Algorithm," vol. 08, no. 01, pp. 1-94, 2018.

[3] T. I. Sariyo, Y. Yohannes, and Daniel Udjulawa, "Klasifikasi Jenis Jamur menggunakan SVM dengan Fitur HSV dan HOG," 2020.

[4] Y. Yohannes, "Deteksi Teks Secara Otomatis Pada Natural Image Berbasis Superpixel Menggunakan Maximally Stable Extremal Regions dan Stroke Width Transform," J. Tek. Inform. dan Sist. Inf., vol. 3, no. 2, pp. 332-343, 2017, doi: 10.28932/jutisi.v3i2.630.

[5] M. K. N. Mursalim and I. Verdian, "Analisis Perbandingan Kinerja Metode Superpixel dan Gradien berbasis Edge Detector pada Pendeteksian Objek Bergerak," ELKOMIKA J. Tek. Energi Elektr. Tek. Telekomun. Tek. Elektron., vol. 8, no. 2, p. 362, 2020, doi: 10.26760/elkomika.v8i2.362.

[6] Yohannes, V. Ayumi, and M. I. Fanany, "Multimodal decomposable models by superpixel segmentation and point-in-time cheating detection," 2016 Int. Conf. Adv. Comput. Sci. Inf. Syst. ICACSIS 2016, pp. 391-396, 2016, doi: 10.1109/ICACSIS.2016.7872729.

[7] T. Ummah, "Deteksi Kendaraan Menggunakan Histogram Of Oriented Gradients dan Real Adaboost," 2017.

[8] Y. Yohannes, Y. P. Sari, and I. Feristyani, "Klasifikasi Wajah 
Hewan Mamalia Tampak Depan Menggunakan k-Nearest Neighbor Dengan Ekstraksi Fitur HOG," J. Tek. Inform. dan Sist. Inf., vol. 5, no. 1, pp. 84-97, 2019, doi: 10.28932/jutisi.v5i1.1584.

[9] M. E. Al Rivan and Y. Yohannes, "Klasifikasi Mamalia Berdasarkan Bentuk Wajah Dengan K-NN Menggunakan Fitur CAS Dan HOG," J. Tek. Inform. dan Sist. Inf., vol. 5, no. 2, pp. 173-180, 2019.

[10] Y. Yohannes and M. E. Al Rivan, "Penggunaan Global Contrast Saliency dan Histogram of Oriented Gradient Sebagai Fitur untuk Klasifikasi Jenis Hewan Mamalia," Petir, vol. 13, no. 1, pp. 80-85, 2020, doi: 10.33322/petir.v13i1.908.

[11] D. Nurdiyah and I. A. Muwakhid, "Perbandingan Support Vector Machine dan K-Nearest Neighbor untuk Klasifikasi Telur Fertil dan Infertil Berdasarkan Analisis Texture GLCM," J. Transform., vol. 13, no. 2, p. 29, 2016, doi: 10.26623/transformatika.v13i2.324.

[12] M. Ichwan, I. A. Dewi, and Z. M. S, "Klasifikasi Support Vector Machine (SVM) Untuk Menentukan Tingkat Kemanisan Mangga Berdasarkan Fitur Warna," MIND J., vol. 3, no. 2, pp. 16-23, 2018.

[13] D. Alamsyah, "Pengenalan Mobil pada Citra Digital Menggunakan HOG-SVM," Jatisi, vol. 1, no. 2, pp. 162-168, 2017.

[14] D. Amputri, S. Nadra, G. Gasim, and M. E. Al Rivan, "Perbandingan Jarak Potret dan Resolusi Kamera pada Tingkat Akurasi Pengenalan Angka kWh Meter Menggunakan SVM," $J$. Inform. Glob., vol. 8, pp. 7-12, 2017.

[15] E. Wang, S. Zheng, Q. Zhong, L. Li, and Q. Zhang, "An Early Warning Method of Pantograph Horn Driling Based on Superpixel HOG Algorithm and YOLOv3 Smart Detector," vol. 3 , no. 2006 , pp. $148-$ 156, 2020.

[16] I. Gandjar, W. Sjamsuridzal, and A. Oetari, Mikologi Dasar dan Terapan. 2006.
[17] H. Zhang, C. Wu, L. Zhang, and H. Zheng, "A novel centroid update approach for clustering-based superpixel methods and superpixelbased edge detection," Oct. 2019.

[18] P. Wlodarczak, Machine Learning and its Applications. University of Southern Queensland, Toowoomba, Queensland, Australia: CRC Press, 2020.

[19] Z. Si and S. Zhu, "Learning Hybrid Image Templates (HIT) by Information Projection," IEEE Trans. Pattern Anal. Mach. Intell., pp. 1354-1367, 2012. 